\title{
Business Environment and Accounting System in Kosovo: Comparison of Different Periods
}

\author{
Muhamet Aliu \\ Prof.Ass.Dr., Economic Faculty, University of Prishtina, \\ Arbana Sahiti \\ MSc, PhD Candidate, Teaching Assistant, Economic Faculty, University of Prishtina, \\ Arben Sahiti, \\ PhD Candidate, MSc , Teaching Assistant, Economic Faculty, University "Kadri Zeka" Gjilan,

\begin{abstract}
Kosovo has undergone structural and fundamental changes in its business environment and accounting system from the period before 1999 under the rule of Yugoslavia, and after 1999 until today, after the liberation and its independence. This qualitative research attempts to compare both periods, and to analyze the decisions that were made throughout the time.
\end{abstract}

Keywords: accounting, environment, CEFTA, SAA, businesses.

\section{Introduction}

Business environment and accounting system is of paramount importance for a country that aims to pursue systematic growth and development. Countries that have managed to adopt right policies and procedures in doing business, have managed to establish a solid base and comparative advantages as oppose to other countries to attract foreign investors.

Business environment and accounting system in Kosovo had undergone thorough changes from the period before the war of 1999, and now. During the Yugoslav era, under the socialist system, most of the things relating with business environment were centralized and dictated accordingly. Whereas, now in the opened and liberal market, there are many outside forces that impact directly and indirectly Kosovo's market and economy, and as such, adaptive changes have been made continuously to fit ever changing environment.

Kosovo gradually and steadily has entered in free trade agreement and negotiations with different countries. It has heavily invested to enhance its institutions and environment in doing business in order to compete with other surrounding countries for a sustainable economic development.

\section{Business environment and accounting system in Kosovo before 1999}

Accounting system in Kosovo prior to 1999 has operated under the jurisdiction of Serbian accounting system, respectively Yugoslav, due invasion that has occurred for many years. Organization of legal and formal accounting system before 60's has been organized under the auspices of a governmental agency called "Social Accounting Services".

Data and information that businesses was supposed to produce to the agency and external users have not been of the appropriate level to enable them to make informed decisions during the decision making process, and the control to reduce their costs and to maximize business value in the market. 
In 1968, there was an attempt to unify the chart of accounts for enterprises to satisfy their needs of the regulatory agency against preferences of the Social Accounting Services. Consequently, the three-digit number of mandatory accounts has been reduced temporarily, and the financial statements and the income statement have taken a more appropriate form.

From 1974 to 1988 the two versions of the codes of accounting principles are adopted by financial experts as well as by the Yugoslav association of accountants to be suitable for the needs of the market gradually. In 1989, the new federal law was created, and that has defined well-functioning of accounting of the activities in the accounting system. This law has established new formats of the balance sheet, the income statements, as well as profit distribution statement.

The idea was that these financial statements with the new format to correspond with the fourth Directive of the European Community and the Laws of the Company. Also, during this period, new version and the last of the Yugoslav Code of Accounting Principles is adopted before the beginning of the disintegration of various individual countries in Yugoslavia.

In early 1990, experts and accountants from different countries of Yugoslavia in government under the direction of the governmental agency have prepared sixteen (16) accounting standards that are put in place during 1991 (Petrovic dhe Turk, 1995).

During this period, there was an attempt to make the harmonization of accounting standards with western economic model. It should be noted that during this period, the power of decision-making has been compelling, and the input of Albanians has been minimal due to the political circumstances that have prevailed at the time compared with the Serbs, Croats and Slovenes.

The business environment in Kosovo prior to 1999 has been based on social economic system. The importance of accounting and professionalism of accountants has been marginalized because during the entire period, the role of accounting information and data have been biased to meet the needs of the federal government.

The functioning of the accounting system has been largely formal, Businesses have received detailed instructions from the competent offices of the Social Accounting Service to compile financial statements.

Accordingly, during this period accountants did not have such an active role, because there was required a high level of professional skills of accounting compared to nowadays. It should be noted that the social system did not enable the development and promotion of private business sector, but the focus has been on social enterprises. Strict laws and directives as well as the nature of the operation of the accounting system has prevented businesses to invest to in order to explore the greatness of accounting in order to increase the efficacy for their businesses (Walton et al., 2003).

During the period before the war, demand, production, supply, and prices have been dictated by the state and not by market demand. These anomalies have led to increased inefficiency of businesses. In cases where social enterprises have operated at a loss, they were covered by state funds. One such controlled and organized system of the economy has fueled inflation in many cases to the very higher figures, which has led to huge losses of the values of products and asset and have undermined the system of economic organization.

Furthermore, private businesses of Albanian owners have been oppressed constantly compared with Serbian. They often have come under pressure of strict accounting of regulatory authorities and has consistently been an attempt to undermine their success.

\section{Accounting System in Kosovo after 1999}

Kosovo during this period of the war and occupation for dozen years, it begins its transition from a starting point which was very difficult. Nineties was characterized in Kosovo with very poor economic policies, weak financial institutions, very high unemployment rate where it is estimated that over half of the population were unemployed besides that, also among them the poverty was more evident.

The transition of the reconstruction phase after the war was very fast due to the enormous financial assistance and international expertise, as well as diaspora remittances coming from around the world. This has had a positive impact on economic and social development, as well as comprehensive economic sustainability of the state of a newborn that was 
under development. Like many countries of Eastern Europe that suffered some year after the transition of the systems change social-economic and political liberal and democratic transition in Kosovo has not been completed, but is ongoing.

Immediately after the war of 1999, the business environment, takes a another direction due to the lack of public institutions in terms of market regulation and organization of the accounting system. This has been a time of art for many new entrepreneurs where Kosovo had the opportunity to benefit from this period since businesses were not obliged to pay any taxes on their business activities. The interim government formed at the time were alongside and supported mainly by international donations that come mainly from the EU countries and the US. It should be noted that the focus of the international community during this time was focused on the political aspect, with particular significance was the preservation of security and stability, due to lack of legislation of the new state of Kosovo, the structure of the system of accounting, compilation and submission statements and financial reports and control was organized by the earlier Yugoslav laws on this phase of transition that Kosovo was passing.

Year 2001 marks an extraordinary reach in the field of accounting system in Kosovo after the approval of UNMIK Regulation 2001/30. With this law, it was formed the Kosovo Board for Financial Reporting Standards (KBFRS) that determines the standards in relation to an accounting of business obligations and audits that are required to be exposed including internal stakeholders and external. Accordingly, regulatory structures was created for accounting and auditing (UNMIK, 2001).

On the basis of this law, KBFRS was obliged to issue laws of Kosovar accounting standards (KAS) and amend them as necessary based on their international financial reporting standards (IFRS) taking into account also climate and business environment. It should be noted that the law that regulates the functioning of the accounting system requires all corporations and public and social enterprises to prepare and present their financial statements in conformity with IFRS standards or KAS.

On the other hand, all the small and medium enterprises are obliged to prepare the financial statements on the basis of the tax rules in effect. Furthermore, the financial reporting of banks and insurance companies made are prepared pursuant to IFRS the the Banking and Payments Authority of Kosovo (BPAK).

In the year 2001, there was approved 19 KAS, which have been replicated versions of equivalent with IFRSs at the time. Because donor support did not continue further, and a lack of formation of a council of the establishment and monitoring of these standards, KBFRS does not had the opportunity to renew KAS conform changes of IFRS made by the International Board of accounting standards (Deloitte, 2013).

In 2011, the Assembly of Kosovo approved the law no. 04 / L-014 on Accounting, Financial Reporting and Auditing (Assembly of the Republic of Kosovo, 2011). Accordingly, it is also established the Kosovo Financial Reporting Council (KFRC) that has the obligation to issue and amend KAS based on IFRS, and also in harmonized to EU directives. For the moment, there are also 19 SKK, but compared to previous years, Benchmarking are much closer to those of IFRS as a result of the work of KFRC.

According to the law on accounting, financial reporting and audit, and auditors' only companies licensed by KFRC can audit the businesses in the Kosovo's market. The law also provides penalties and sanctions for commercial and auditors who do not apply to KAS. Currently, KFRC do not possess an effective mechanism for ensuring that these KAS are implemented by commercial companies. The high level of informal economy in Kosovo economy reflects the application of these standards is not in the right level.

During the period after the war in Kosovo, the changes in the accounting system are also associated with changes in the business environment. The transition from the social economic system, into the liberal has made Kosovo a place of destination for many foreign investors due to the removal of many barriers, licenses, and changes in the labor laws to meet the needs of investors and trends in regional and European level in doing business. Foreign investments in the banking, telecommunications and insurance all that reflects the attractiveness of the Kosovo market.

Some of the foreign companies operating in Kosovo are part of different business groups from their country of origin such as: IPKO, Raiffeisen Bank, ProCredit Bank. The harmonization of the accounting system of Kosovo with the international standards of accounting and auditing has led these companies to be listed through the various European stock exchanges under the umbrella of the group which they represent. 
It is worth mentioning that in 2006, Kosovo became part of the free trade agreement CEFTA (Central European Free Trade Agreement) by joining Albania, Serbia, Montenegro, Macedonia, Bosnia and Moldova. Furthermore, Kosovo has managed to have access to the EU market based on the project of autonomous union preferences and preferential tretment won for some products to be exported to the US (MTI, 2011). This has led to the liberalized economics gradually but rapidly so that Kosovo be in the same trend and stage of development with other countries in the region.

Indeed, liberalization of the market and CEFTA has brought advantages and disadvantages in the economic development of Kosovo. Among the main advantages worth mentioning are:

The possibility that manufacturers and entrepreneurs in Kosovo to have access to a market of 30 million inhabitants.

\section{Elimination of non-tariff barriers}

Discussion of the various trade issues through regional forums

Kosovo is taking advantage of experience and the chance to be taught rules of EU trade

CEFTA is built and operates according to the rules and legislation of the World Free Trade Organization (WTO) where Kosovo one day hopes to become part of it.

On the other hand, membership for Kosovo in CEFTA has several disadvantages due to the political problems that Kosovo has had, was is having with some countries of the region. If we look at the impact of CEFTA in Kosovo with a critical eye and with the objective, we can conclude that membership in this agreement has brought Kosovo not so much benefits at the expected level in the short term. But there are many indications that in the long run, anyway Kosovo is on track to benefit substantially from this agreement due to the gradual growth in the manufacturing sector (MTI, 2013).

Furthermore, the free market and CEFTA has obviously increased competition in the Kosovo market, and has made local manufacturers to invest in technology, to increase the quality and benefit from the new knowledge in marketing, management, and redistribution to be more competitive in the market. Another very important event that happened in the business environment with changes and advancements in the accounting system is the privatization of public enterprises. The privatization process was and continues to be regulated under the laws of UNMIK. Until now, most public enterprises have been privatized, but the results of this process are not positive due to the weak results that are produced. The whole process of privatization has resulted as failed process, there was no transparency in terms of measuring the real monetary value of enterprises prior to privatization.

Also, the Kosovo Privatization Agency (KPA) has failed to monitor the enterprises after privatization process in financial terms to ensure that there were positive results (Knudsen, 2010). Many of these privatized enterprises have not continued to exercise business activity immediately after privatization. Some of them have been turned into residential buildings, large markets, warehouses, and others were sold as residential plots. As a result, the privatization process has not affected the economic development of Kosovo and the reduction of the unemployment rate.

Kosovo has concluded free trade agreement with the government of Turkey. In the October of 2015, Kosovo has also signed the Stabilization and Association Agreement (SAA) with EU. This agreement is expected to remove trade barriers between Kosovo and EU, and promote trade and investments. This agreements foresees that customs taxes for the EU products to be completely removed within next 10 years. As a result, Kosovo is expected to lose about 60 million euros of income. However, Kosovo domestic producers will be able to benefit in the near future in the market of over 500 million inhabitants within the EU. In addition, Kosovo will have access to the Instruments of Pre-Accession Assistance (IPA) II. Until 2020, IPA is expected to invest in Kosovo over 650 million euros to enhance the competition capacities, and therefore, prepare Kosovo to join EU in the future.

\section{Conclusion}

Kosovo, after the war period, despite many barriers it has faced, it has managed successfully to build its institutions and economic framework. Kosovo's economy has gradually opened in relation with other countries and foreign investors. 
Different legislative changes as required were made to adopt the needs and expectations of a free market environment in order to promote the economic development.

The period after 1999, has shown that it is extremely important to create a very friendly business environment in order to survive in such dynamic regional and world economic turmoil and crisis.

So far, Kosovo has managed to become full partner in different economical agreements including the CEFTA, SAA, and the free trade agreement with Turkey, and it's on its path in the immediate future to become part of the World Trade Organization.

\section{References}

[1] Deloitte (2013). Financial reporting framework in Kosovo. URL: http://www.iasplus.com/en/jurisdictions/europe/country70 (accessed 01/04/2013).

[2] European Commision (2015). Stabilisation and Association Agreement (SAA) between the European Union and Kosovo enters into force. http://europa.eu/rapid/press-release_IP-16-1184_en.htm

[3] Knudsen, R.A. (2010). Privatization in Kosovo: the International Project 1999-2008. NUPI report. Norwegian Institute of International Affairs.

[4] Kuvendi i Republikes se Kosoves (2011). Ligji Nr. 04/L-014 për Kontabilitet, Raportim Financiar dhe Auditim. Gazeta Zyrtare e Republikes se Kosoves/ Nr. 11/26 Gusht 2011, Prishtine.

[5] MTI (2011). Investing in Kosovo: Ministry of Trade and Industry. Investment Promotion Agency.

[6] MTI (2013). CEFTA dhe ndikimi i saj ne Kosove. URL: http://www.mti-ks.org/sq/CEFTA-dhe-ndikimi-i-saj-ne-Kosove- (accessed 01/04/2013).

[7] Turk, I. and Petrovic, M. (1995). " History, theory and practice of accounting in Yugoslavia".

[8] The European Accounting Review Vol. 4 No. 4, pp. 809-826.

[9] UNMIK (2001). Rregullorja nr. 2001/30. URL: http://www.unmikonline.org/regulations/unmikgazette/03albanian/A2001regs/RA2001_30.pdf (accessed 28/03/2013).

[10] Walton, P. and Haller, A. and Raffournier, B (2003). International accounting, second edition. Thomson Learning: London. 